\title{
The Waldorf Pedagogy in Natural Sciences: Main Differences Found in Brazilian Curricular Proposals
}

\author{
Samara dos Anjos, Andrezza Abreu, Alice Melo \\ Universidade de Brasília, Brasil
}

\begin{abstract}
This work aims to conduct an analysis of the National Curriculum Parameters (PCNs) in Natural Sciences, comparing traditional school curriculum with that of schools that adopt the Waldorf in Brazil, as regards pedagogical theory and practice. This pedagogy takes a different look at education as it acts with the principles of liberty, equality and fraternity. Education in this pedagogy is developed based on anthroposophy, which is the knowledge of man. This knowledge places man at the center of attention and seeks answers to scientific, social, affective and cognitive questions, so that man can fulfill his possible needs, living harmoniously with the environment. The present work is based on surveys of the literature, observations of classes in Natural Sciences and interviews with teachers and students at Waldorf schools, seeking to understand the differences in teaching and learning in the educational development of the human being.
\end{abstract}

\section{Introduction}

Natural Sciences education has been practiced according to different educational proposals that have developed over the decades as theoretical elaborations and are expressed in the classroom in many ways. Many practices, even today, are based on the mere transmission of information, centering on the textbook and its transcription on the blackboard, while others incorporate advances made in recent decades, the process of teaching and learning in general and teaching Science in particular. The National Curriculum Parameters (PCNs) in Science are addressed to educators who aim to deepen the pedagogical practice of natural sciences at the elementary school, contributing to the planning of their work and the teaching project of the team and the school education system to which it belongs [1].

Waldorf education, founded in 1919 in Germany, is present worldwide. One of the main features of Waldorf education is its reliance on the concept of human development introduced by Rudolf Steiner, the founder of anthroposophy, geograph from an anthropological point of view, pedagogical, curricular and administrative grounded in anthroposophy. Here the human being is apprehended in terms of his/her physical appearance, soul (psycho-emotional) and spiritual aspect, according to the characteristics and age of each one, looking for a seamless integration of body, soul and spirit, or that is, between thinking, feeling and willing [2].

The Waldorf arrived in Brazil in 1956 in Sao Paulo. The first Waldorf School began operating in Brazil, within the Brazilian situation, with the great task of substantiating Waldorf's work, inspired by other schools in Europe.

\section{Waldorf System of Pedagogy}

\subsection{Waldorf teacher training}

The teacher must know the curriculum proposed by Waldorf education and the development of human beings. To teach in schools that adopt this pedagogy the teacher needs to go through specific training lasting at least four years. During this period he/she will undergo not only a theoretical but also a musical and artistic training, which involves a number of areas such as mineralogy, astronomy, eurhythmics, drawing, modeling and painting.

\subsection{Curriculum}

The content dealt with in a Waldorf classroom consists not only of conveying information, but mainly teach to learn. Content relates to the age of the students. Waldorf Education and teaching methods require that the teacher be specially trained. At a Waldorf school, the specificity of materials makes the classroom teaching be divided into primary and class matter [3]. This differs from traditional schools that systematically organize the content as is proposed by the Education Department. In matters theoretical, practical and artistic Waldorf schools are arranged so that the work in the classroom allows alternations, where students can just take a break in order to better assimilate the content, enhancing meaningful learning. Another difference found between the two school systems is the teacher-student relationship that exists in Waldorf schools. The teacher prepares her lessons so that students can achieve individually, so there is a greater concern for each student, for he knows how each one works and the best possible way for the 
student to absorb the knowledge received appropriately.

In the first eight years each class has one 'homeroom' teacher, and the relationship is solidly established because the teacher has the knowledge of every aspect of the student, their abilities, difficulties and so on. For those eight years teaching is about interior development, since if it falls into a mere routine, the classroom will lose its purpose [4]. From the ninth to the twelfth year, the monitoring is done by various tutors and teachers of other disciplines. These professionals are experts in the areas where they operate.

Kindergarten students are encouraged to discover value and keep their cultural values; they learn how to recite poems, sing songs and participate in historical moments using fairy tales, these tales, nourish and stimulate the imagination of children, leading them to understand the milieu and affective relationships. In grandiose images of the tales we find the great guiding principles of human evolution: the original state of harmony and perfection (the kingdom); fall (the stepmother, wandering through the woods), the loss of the original harmony (the world of stones, suffering), temptations (dragons, bad fairies), the awakening of intelligence (dwarves who assist other elemental beings), the soul struggling (the princess in rags, or the prince who goes through difficulties), the final redemption, that is, purification and return to a state of harmony (the happy marriage of the princess with the prince), etc.. In their details, the authentic fairy tales that reveal the hidden source to distant generations contained all the morality that they need, and satisfy their historical curiosity [5]. Through repetition, fairy tales allow children to start to assimilate the stories that are told by the teacher in an artistic way. This is a playful way of working with history and arts to reveal fraternal values.

\subsection{Classes time}

Every day in class the students encounter songs, poems, verses and stories that relate to the topic being discussed in class time. The class teacher can explore the theme in a playful way in order to get students to think, learn and exercise knowledge. The class time lasts an average of two hours and is included in the main class, students are involved in rhythmic activities in order to harmonize them and wake them up for classes.

Students are greeted at the door of the room where the teacher welcomes the class individually. This process occurs in the same way every day, and before starting the lesson students are arranged in a circle or in rows to recite the verse every morning. From the 1st to the 4th year the verse is the same, but it changes from the 5th year student where vision becomes nature.
Verse 1 st to the 4 year

With its light honey

The sun brightens the day

And the power of the spirit

What shines in my soul

Gives strength to my limbs

In the glow of sunshine

Oh God I worship human strength

That you kindly planted in my soul

To that may be

Eager to work

To that I can have

Desire to learn

Ti is light and strength

That for Ti reflow

Love and gratitude.

Verse from the 5th year

I contemplate the world

Where the sun shines

Where stars shine

Where the stones sleep

Where plants live,

And living grow

Where the animals feel

And feeling live

Where the man has now itself soul

Housed the spirit

I contemplate the soul

That resides in me

The divine spirit within her age

As it operates on sunlight

He hangs out in the vastness of space

And also in the depths

I beseech Thee

Oh divine spirit

What a blessing and strength

To learn

For the working

Grow inside me.

\subsection{Organization of series / periods}

Rudolf Steiner organized Waldorf Education in seven-year periods:

- From 0 to 07 years (school maturity) the children pose as a reference the teacher and start to imitate him. Children do not understand the thinking of adults, are open to the world, do not analyze or make judgments. This period corresponds to Kindergarten, the focus is on the development of creativity and imagination of the child, respecting his ability and his talent.

- From 07 to 14 years old (sexual maturity) is the period when feelings and sensitivities arise toward other teenagers, corporal and psychological changes occur, and students see the teacher as "beautiful". This period corresponds to the elementary school, where the scientific and investigative spirit is cultivated. It has the same educational curriculum as 
other schools, with additions such as music, gardening, astronomy, English, German and so on. - From 14 to 21 years (social maturity) is the period in which logical, analytical and synthetic development takes place, and there is a need for intellectual and conceptual explanations for the various questions that arise. Teenagers who are already almost adults seek to be understood. The teacher is seen as "true". This period corresponds to high school, students are prepared for today's world, with emphasis in vestibular.

\subsection{Evaluation}

Students in Waldorf schools are not repressed as occurs in traditional schools, where the end of each year the student receives a newsletter containing mathematical data quantitatively demonstrate that your income may be positive or negative. The assessment will not be made by numbers, but by means of a qualitative characterization. This will encourage, emphasizing what is positive and negative criticizing only in relation to the student, being able, could produce [2].

\subsection{Anthroposophy}

The Waldorf is governed by Anthroposophy, this cannot be considered a religion, it is not passed in no time to the students, because it respects the spiritual choice of each individual. Thus, Lanz explains: Anthroposophy is science! But it is a science that pushes the boundaries with which hitherto bumped science 'common'. It proceeds by scientific observation, description and interpretation of the facts. And it is more than a theory, a building of statements. Indeed, she admits and recognizes all common findings in the natural sciences, although with complete and interpret their findings. Especially has made in all areas of practical life, many contributions and innovations concrete and positive which is the true touchstone of its principles [5].

\subsection{The current context of Waldorf Education in Brazil}

With 92 years of existence and even having a fairly educated pedagogical basis is still not possible to verify many Waldorf schools in Brazil. That's because there are still difficulties to establish in law a Waldorf school, there is often a bias on the part of lay related to anthroposophy.

According to the Federation of Waldorf Schools in Brazil (FEWB) there fifty-three schools, which comprised eight schools that have through high school, eighteen schools that are up to the elementary school (some only until the 5th. Annum) and twentyseven gardens Children of independent, they clustered around the seven regional spread throughout the country and through these regional FEWB are affiliated to. The difficulties in establishing, within the law, a Waldorf school is evidenced below by a member of the Federation of Waldorf Schools in Brazil. After the promulgation of the Brazilian constitution in 1988, groups of educators and educational bodies, began organizing a bill that would replace the current LDB season. This project that was being made on a new conception of participatory democracy, having been passed in the House of Representatives, was replaced in the Senate by Darcy Ribeiro project in March 1996. Everything indicates that the project, after some modifications converted into the new Law of Guidelines and Bases of National Education, advice of people who had occupied or occupy positions in the Ministry of Education. This new LDB, called by some authors as "minimalist", because it contains few regulations, gives wide latitude to present their pedagogical schools, and has incorporated some innovative concepts for most schools as the issue of progression the student, the respect for the relationship age / grade, important aspects will Waldorf [6].

Waldorf schools are charities, nonprofit, not receiving government aid, remain only with donations and tuition costs for students, thus covering its possible costs.

\section{Methods}

The methodology of research and analysis of the curriculum of schools that adopt the Waldorf in Brazil and the National Curriculum for the Teaching of Natural Sciences. The research work was divided in stages: Stage 1 - Analysis of the curriculum at a Waldorf school curriculum component for Natural Sciences. Step 2 - Analysis of pedagogical practice described to classes according to the Natural Sciences curriculum in Waldorf schools. Step 3 Follow-up of 20 hours of instruction in school Waldorf Moara Brasilia (Brazil) in the second and third year, noting the progress and content of the classes of Sciences addressed. At this stage, were recorded in a logbook of all classes, practices, involvement of the teacher and students in the classroom. Step 4 - Analysis of the Waldorf school curriculum, lessons observed and compared with the performance of PCNs. To perform the comparison we used the following criteria:

- Contents suggested for each term in public schools teaching 2nd and 3rd grade, according to the curriculum of the Department of Education of Elementary School early years of the Federal District.

- Contents suggested by the annual planned and developed curriculum for every Waldorf teacher for classes 2nd and 3rd year.

- The bimonthly SEEDF dates and times of classes in Waldorf. 


\section{Results}

The results will be part of a diagnostic plan for future studies, research, innovative ideas and possibilities in Natural Sciences. According Bachega [6]: It is expected a School Waldorf form the human being and not just fill each with contents that are not always used in their daily lives. And it's not the reason these students do not have a rigorous study of content that will make them less able than others, because the emphasis is to teach and learn. With this as the cornerstone of Waldorf education, learning content becomes merely the result of construction of the human harmonious and well developed.

Following the literature review and theoretical, we conducted a visit to the school Moara where a Waldorf teacher was interviewed. It was possible to know the school environment, and the structure of education addressed to Waldorf mentioned in books and articles read in the first stage of the research. Professor Olga has studied ten years in a private school and three years in public school, after high school, she went straight for the entrance exam of UnB two years of music making, the course stopped after three and a half years, he started working as a teacher English, was teaching adults in the same period received an invitation to work at the embassy of Germany, when he returned, met in Brasilia waldorf pedagogy - Moara School, where this year he was born. During this period there was a workshop in which UNB gave training courses for teachers become teachers Waldorf. Professor Olga was a striker in the assembly of the first course in Brasilia this course that lasted four years. Currently there are three classes with training in Waldorf. The following is the script and the answers of the interview with the teacher Olga Waldorf.

Interview

1-What is the main difference between the teaching practice of a traditional teacher to a Waldorf teacher?

The main difference I see, the intimate connection with the student's teacher, the connection he has with the kids and not the content, I will not give the first fifteen years of my life the same content in the second year. A waldorf school teacher prepares the student in student thinking, how to reach the student's knowledge, because the normal school is all very punctual, I would even say that Waldorf education is individualistic, she sees each individual as each student including the teacher.

2- Learning in science teaching in traditional schools is based on observation, experimentation and practice. How does the teaching of science in school waldorf? What are the main differences?

What strikes me is that the first to the fifth year teaching is not very objective, but it is working in a practical way, and when viewing images from the sixth year that the picture changes, students see the concepts of scientific way.

3- The Waldorf education at school can only occur through direct contact between teacher and student. What is the duration of the contact and how it occurs?

Whenever a student is enrolled in school, there is a first interview to get to know the school and Pedagogy, if the family decides she enrolls, always, always all class teachers and class teachers of early childhood education make a personal interview with family, that the father and mother tell about the history of the child to know who this child is coming. The contact with the family, depending on the family's daily at the door before class begins and after it ends. So there are so bimonthly meetings of evaluation that we did not have notes, so there meeting. And then so, whenever the teacher or family perceives anything or needs to talk, the other one seeks and marks a time to talk about the child, about what is worrying, there is this exchange, she is encouraged by the school ever, since it has the heritage, this practice, their parents are entering this rate, one thing is very variable even from family to family, but because he has family that leaves the child in school and not enter the school, I have a father who let his son on the door handle and the door and refuses to talk to us strictly, he has less time available, it comes at parties, meetings does not come, do not come at all, now the mother, they are separated, the mother I have more contact, but her mother travels the mother be working, but once it is closer. You can tell how I feel like boy's aunt, because you need hosting, I know about the family situation of the boy, he spends the whole day at home with his brother and the maid, he only has contact with adults he is super big head, has a hell of laziness to do anything to draw, but to tell the amoeba, protozoa in the deep ocean do not know of many on the meteor now, because the helium, the sun is formed helium and hydrogen teacher, then I ask him you saw? Because I'm only seeing the light and feeling the heat of it, not to see it there that you are talking about. Got it? I have to bring it forth, hugging him a little, he has great difficulty, that of knowing family history, it helps us a lot, even more than I'll stay with him long.

4- If the materials are set according to the age of the students is held as the choice of the theme of the same?

There is a well-defined curriculum in relation to content, all the issues in relation to age. So, for example, hygiene is a family practice right? So that means family practice that continues in the room, ai in this case I feel kind of like children's mother, if I see that someone is missing hygiene, I'll talk it over there and teach the way I teach combing the hair, I look I have a comb here in the room, and half again have someone who forgets to comb his hair. Oh well, 
the culture is embedded inside the classroom, Brasília has a lot of respiratory problems in the dry season, June was ten times a day every boy in the bathroom, you know a lot of people have the flu, that whole thing going on here. So well, that sort of thing, it's one thing to practice inside room with children. Now, when you bring a hygiene issue, it's for life! In the seventh year, when the child is thirteen years. And by the indications of Steiner, it indicates that at this age, because after the fourteen enters nutrition, ecology goes there in terms of the environment consciously, because at that age they will be able to absorb and bring to life [...].

5- Why even with 90 years of existence and with a pedagogical basis well educated, there are so many schools Waldorfs in Brazil?

Each Waldorf School is an initiative of the place itself, is not a multinational huh? Despite worldwide and everyone is supporting this local initiative and thus schools are usually nonprofit associations, like you arranges money to purchase equipment. And woe to us, for you to open a school from a group, the group must have enough strength to make it happen and how are local, you also do not see people studying anthroposophy and who are interested in spreading it around Brazil usually more passionate people to go where it has more concentration of anthroposophy, so people who have already left because of Brasilia wanted to continue the study until the end and settled in Botucatu, São Paulo which is the large local concentration of anthroposophy, was people who left Florianópolis Santa Catarina, thank God, because there has school until the ninth grade and is guaranteed for that child, you know. So people, when they come to a Waldorf school, usually the mouth, not the media, or because studied anthroposophy, already had contact with anthroposophy, usually already have some prior knowledge. Alas they seek the school and the school is made up of people who believe in this methodology. I see that these initiatives are so slow, I still really surprised me when I remember that has more than 1200 Waldorf schools worldwide in 90 years, which is Pedagogy you know who grew up that way? Understand?! And so in Brazil if I'm not mistaken are more than fifty gardens Waldorf in fifty years, is born as a school per year, and has over fifteen elementary schools and seven high schools, so it is little compared to the size of Brazil, but in China the first school was born in 2004, you see!

6- As a Waldorf school is a school with principles of liberty, fraternity, equality, should probably have had histories of pupils with dyslexia, psychomotor difficulties, among others. As the teacher works with these students? They are referred to special classes?

These students are usually in the same class with students their age usually much depending on each case and what the student does in class is what he realizes, and the teacher gives special attention to students is possible, all that is talked with parents, and if there is a parental preference of having the student in that room here to remembering who was thirteen at the time that his colleagues were doing ten, he was the more softly, he barely touched the ground, he just walked on tiptoe, he had a hard time absorbing, alas now I do not know if it was production or absorption of air in their body that committed the motor and cognitive development and he was much more quietly than other children of ten years, much more quietly, and he knows, he wrote accounts so if you're talking about math 3rd year already started having equations right? Fraction, and he could barely make counts to fifty, the four basic operations with numbers up to twenty-five, thirty. But it was a condition he was in the room realized what he was there inserted in social and we see this as a very important thing, but not was absorbing everything that the other kids were in school and Waldorf is common to have a person skilled in curative education, which is a branch of anthroposophy, it is common to have a nutritionist, psychologist, psychology is a differentiated, which is an artistic approach to the child and the relationship with dyslexia, there is at least one in each class and dislexo this various approaches to the same subject for children, help a lot dyslexia too, because in 1st year when they begin to make literacy, to be literate and know the lyrics, one of the ways the teacher is working the letters in a room with play dough dyslexia and it has to do with this perception of letters in three dimensions, because it is as if the dislexo saw those letters or word this seeing it in many ways, now he rides that word, he will never forget that one word is [...].

With comparisons made between the curricula of schools using Waldorf education and the curriculum proposed by the Secretary of Education of the Federal District, it was possible to note that the approaches of Natural Sciences held in both teaching methods are given for different pedagogical practices, each institution education follows the contents proposed by the Secretary of Education of the State, but these contents are not in the same order as such, and schools that adhere to Waldorf these contents are not worked piecemeal, as the content covered in textbooks and in classes of Natural Sciences of public schools in the District. Moreover, the playfulness, the bodywork, cognition, experience and other aspects are quite evident with students who have contact with Waldorf pedagogy, making this way of learning, significant. And this is only possible because there is adequate training for teachers of Waldorf and intense active participation of students' families.

After monitoring 20 hours classroom at school Moara in Brasilia was possible to compare the resumes of the 2nd and 3rd year of Waldorf with the 
2nd and 3rd series of first and second cycle of basic education.

The following is a comparison of the contents of Natural Sciences between the contents of the Secretary of Education of the Federal District (SEEDF) with possible contents of schools that adopt the Waldorf.

\section{2nd YEAR}

Waldorf and SEEDF

1st Bimester - Universe and Earth x Season 2 Science and Geography: In SEEDF students of 2nd year studying this period concepts related to the Universe and Planet Earth, they develop skills that if agree in the differentiation of environments, the time, the distinction of day and night as well as to observe the various positions which occupies the sun throughout the day. Students at Waldorf studying at that time concepts related to water. Through the hydrological cycle students are called to grasp the relationship of living things and the physical environment. There is a similarity in that period between the proposed contents of the two curricula.

2nd Bimester - Life and environment $x$ Season 3 - Natural Sciences and Social: The third time students from Waldorf begin to experience content linked the theme of the universe and solar system, this students spend time observing the nature that surrounds them, the themes are explored and worked through music, bodywork and through the mother tongue texts that are connected with the theme of time, to observe the physical environment students are able to establish a relationship with the social environment. In the same time the students spend the SEEDF make their first contact with the chemistry of the surface, is treated in the first room features solid, liquid and gas, in this period the students also get to know the contents linked botany.

3rd Bimester 25 - Technology and Society $\mathrm{x}$ Season 6 - Nature and Mother Tongue: In this period the students SEEDF continue to study contents that are related properties of air, either through experiments, observations and records readings or productions of texts, where they pass through these activities to recognize the wind at your back. In the same period of Waldorf students begin to see concepts related to nature, plants, starting for the ecology and botany superficially. Finally students are using their creativity to productions of texts, such as creating stories.

4th Bimester - Health and Human Season x 8 Matthew, Social and Natural Sciences: Students of SEEDF spend that time studying a subject facing the human body, comprising component parts and systems of the human body. By knowing the body, students are called to respect the similarities and differences found in humans, these differences individual, social, ethnic, racial and cultural backgrounds. Students studying this period of Waldorf content connected to the Universe, then knowing the Earth system, students begin to increase insight and knowledge by studying what lies beyond the planet.

\section{3nd YEAR}

Waldorf and SEEDF

1st Bimester 08/02 to 24/04 - Universe and Earth x Season 3 09/04 to 05/05 - Mother Earth: Universe and Earth x Mother Earth: The two curricula address the topic of planet earth in different ways, the curriculum SEEDF content part of the macro to the micro, the universe and everything in it for the understanding of the Earth system. At Waldorf school curriculum is approached Earth as a source of production, planting seeds and fruits generation. The content is treated more specific this time stepping into a deeper geological context. Another similarity found between the two curricula is the occupation of the people inside the camp. Shown is the kind of activity that is performed by a farmer or peasant for example. Students at Waldorf this period do not study issues related to the Universe, as the solar system, lunar among others. The Portuguese language is crafted in class season Sciences through texts, poems and songs.

2nd Bimester - Life and environment $x$ Season 7 - House: The curriculum SEEDF are addressed contents linked life and the environment, it is suggested that teachers work issues related to soil and power of living beings, be they animal or vegetable order, as explained before the contents are presented to the students of the macro - the micro universe - Earth, this time the students come to understand the importance of soil as maintenance of life on Earth is organized and how the cycle of life that is in the environment. In that same period Waldorf curriculum students learn in a practical way on professions, tours are conducted for students to know the uniqueness, importance and role of each profession within society, students learn what it takes to build a house, for example, what types of sand may be used or which one (s) material (s) the mason can use to make bricks. Students can also know the work of farmers, which is the appropriate time for planting, how much fertilizer and water can be used in this process. With the study of soils is possible to make a connection with an interdisciplinary theme of professions and environment. It is important that students know the different types of professions that may be exercised within society in order to know the working of all is key to a city, state and / or country progress.

3rd Bimester - Technology and Society x Season 8 - Math: In the curriculum of SEEDF are addressed content related to the natural sciences, so that students start to understand the chemical composition and soil physics. During this period students learn that the chemical and physical transformations of materials can contribute to the formation of products that are useful in our day-to- 
day and that assist in the quality of life of populations. In the same period Waldorf students are entering a new era, are taught math classes. There are similarities between the two curriculums in this period.

4th Bimester - Health and Human Season x 9 From grain to bread: The curriculum SEEDF proposes that teachers work issues related to food and health. Students learn the importance of a balanced diet, food sources and the main differences between natural and processed foods. The topics covered are similar to what students see in Waldorf, this period still using the theme of earth and soil, students learn about the transformation of grain into bread, food very well known and appreciated.

\section{Conclusions}

The methodology used in schools that adopt the Waldorf is quite different, and this contributes to a significant and consistent learning for students. The experience is a "tool" more important within this method, it has a student of character and intense contact with the individual teacher, it allows him to establish a deep bond, intimately knowing each student, their difficulties, capabilities and fears, seeking work on the needs that each student has.

In the traditional school science classes are punctual, there is an approach toward the preparation of content, classes are generally expository, support the teacher uses on a large scale is the textbook and as proposed in the curriculum there is always the oral record and / or written, which may make this way more theoretical classes. The content is mostly exposed on the board where the student participates in an 'indirect', just copy and interacts little. Traditional schools follow the curriculum that is offered by the Education Department. In Waldorf schools, classes are prepared in order to attain knowledge of the student, the student is introduced to the world. The classes are started with songs that relate to the lesson time. No textbooks are used in classrooms, each teacher to use part of their knowledge, their experiences (travel, reading) that way the class is assembled. There multimedia resource utilization as well as the use of ready images. "The image of little use as a teaching resource in the teaching of Waldorf Education is a way to encourage children to draw their own pictures. These images (once internalized) will be transformed according to the development and maturity of the child. On the other hand, if the child receives images so ready, they will be saved in memory as 'concepts dead' that explains in part the restriction of Education waldorf television, computer and video games [8].”

The themes proposed in PCNs - Parameters curricular National Curriculum and the Education Department are worked, but teachers alternate the issues and prepare their lessons then adding music, languages, painting, poetry and theater. Learning science in elementary education is mainly the recognition of the world and a first construction of explanations. Guided in scientific explanations, learning progresses, began to constitute new ways of thinking student. [9]

Another important factor in this pedagogy is the constant participation of parents in educational development of their children. Meetings are held, field activities, where parents are actors that assist in building the knowledge of the students. The waldorf schools incessantly promote and support this environment interaction between parents and children. The society today leaves the responsibility for education, transmission of values and moral only in charge of the school. They forget that this responsibility begins within the child's own home, within the family.

\section{Acknowledgements}

We thank for participating in volunteers Scientific Initiation Program - ProIC, the National Council for Scientific and Technological Development - CNPq, the Deanship of Research and Graduate University of Brasilia - UNB.

\section{References}

[1] Brasil. Constituição (1988). Constituição da República Federativa do Brasil. Brasília, DF, Senado,1998.

[2] Lanz, Rudolf. A Pedagogia Waldorf - caminho para um ensino mais humano, 9. ed. São Paulo: Antroposófica, 2005.

[3] Lanz, Rudolf. Noções básicas de antroposofia. 4. ed. São Paulo: Antroposófica, 1997.

[4] RICHTER, Tobias. Objetivo Pedagógico e Metas de Ensino de uma Escola Waldorf. 1. Ed. São Paulo, 2002.

[5] MIZOGUCHI, Shigueyo Miyazaki. Federação da Escolas Waldorf no Brasil. Available at: $<$ http://www.sab.org.br>. Access Date: 14 November, 2011

[6] BACHEGA, César Augusto. Pedagogia Waldorf, um olhar diferente à educação. v.1, n.1, Paranaíba, 2009

[7] CURRÍCULO - Educação Básica - Ensino Fundamental - Série anos inicias. 2010.

[8] Lanz, Rudolf. A Pedagogia Waldorf. São Paulo: Ed. Antroposófica, 2000

[9] BRASIL. Secretaria de Educação Fundamental. Parâmetros curriculares nacionais: Ciências Naturais/Secretaria de Educação Fundamental. Brasília: MEC/SEF, 1998. 